\title{
Lze rozřešit spor mezi realismem a konstruktivismem?
}

\section{Can the dispute between realism and constructivism be resolved?}

\author{
Tomáš Marvan \\ Filosofický ústav \\ Akademie věd České Republiky \\ Jilská 1, 11000 Praha 1 \\ marvan@flu.cas.cz
}

\begin{abstract}
Abstrakt/Abstract
Text se formou polemiky zabývá otázkou, zda je možné rozřešit filozofický spor mezi realismem a konstruktivismem. Oproti mínění Jaroslava Peregrina hájí autor tezi, že tento spor rozřešit lze, a to ve prospěch realismu. Argumenty pro realismus jsou výrazně přesvědčivější, zatímco konstruktivistické argumenty nejsou ničím podložené a zároveň vedou $\mathrm{k}$ absurdním důsledkům.
\end{abstract}

The text adresses, in a polemical fashion, the question whether the philosophical dispute between realism and constructivism can be resolved. Against the opinion of Jaroslav Peregrin, the author defends the thesis that this dispute can be resolved, in favor of realism. The arguments for realism are much more convincing, while constructivist arguments are baseless and at the same time lead to absurd consequences.

Ve svém textu Realismus, relativismus a trápení ducha ${ }^{1}$ Jaroslav Peregrin předkládá kritický rozbor vybraných tezí a výkladových hypotéz mé knihy Realismus a relativismus. ${ }^{2}$ Některé jeho výtky na mou adresu bych přijal jako opodstatněné, jiné nikoli. Nebudu však pokoušet čtenářovu trpělivost detailní polemikou s Peregrinovými námitkami a zaměřím se jen na to, co vnímám jako jádro našeho sporu.

\footnotetext{
${ }^{1}$ Peregrin (2014); dále jen RRTD.

${ }^{2}$ Marvan (2014); dále jen RR.
} 
Peregrin se zamýšlí nad obhajitelností realistické pozice a potažmo nad smysluplností debaty mezi realisty a konstruktivisty. ${ }^{3}$ Je přesvědčen, že tato debata je jen ztrátou času, protože ji nelze rozřešit. Nelze přinést rozhodující důkaz pro realismus, byt' jej také není možné vyvrátit. Já jsem se dle něj dopustil té chyby, že jsem si popletl nevyvratitelnost realismu s jeho prokázáním. Jelikož je ale dle Peregrina nevyvratitelný i konstruktivismus, je třeba celý spor opustit a věnovat se jiným filozofickým otázkám. Já se naopak domnívám, že debata realismus/konstruktivismus rozřešitelná je, byt' pro realismus, který v knize hájím, nacházím jen řadu nepřímých důkazů. Pokusím se proto čtenáře znovu přesvědčit o tom, že argumenty pro realismus jsou výrazně přesvědčivější.

Realismus podle Peregrina připouští, že „některé teorie porcují přírodu tam, $k d e$ má skutečně klouby ..., zatímco jiné nikoli“.4 Otázkou je, jak takové teorie poznáme. Peregrin se domnívá, že je poznat nelze, a od toho se odvíjí jeho skeptický pohled na debatu realistů s konstruktivisty.

Zdá se mi, že jediným vodítkem nám mohou být ty naše teorie, které budeme považovat za nejlepší - ty, které se nám budou zdát nejlépe fungovat. Pak ale bude „odpovídání struktuře reality“ [...] jenom, jak by řekl Rorty, prázdným komplimentem skládaným těm teoriím, které fungují. To jest nebude jasné, nač nám řeč o „struktuře existující ve světě bez pojmů“ vlastně je. ${ }^{5}$

Jinde Peregrin představu „odpovídání struktuře reality“ zostra charakterizuje jako „hloupé pseudovysvětlení“. 6 Podle mého názoru je nám řeč o struktuře existující ve světě bez pojmů dobrá např. k tomu, abychom mohli odpovědět na otázku, proč ty teorie, které dobře fungují, vlastně fungují. Pokud se na nějaké takové množině fungujících teorií shodneme, realista může jejich úspěšnost nekruhově a netriviálně vysvětlit: „Tyto teorie fungují, protože odrážejí na nás nezávislou strukturu reality.“ Naproti tomu, Peregrin s Rortym zde mohou jen konstatovat, že ty teorie ,prostě fungují“. Ponechám na čtenáři, aby zhodnotil, která z obou odpovědí více připomíná pseudovysvětlení.

Peregrin sice hovoří o fungujících teoriích, ale problém můžeme reformulovat již pro samotné pojmy, jimiž realitu zachycujeme: pro pojmy vrabce, řeky, kvarku, temné hmoty apod. a pro pojmová schémata, jichž jsou tyto pojmy součástí. Peregrin svou námitku proti sporu realismus/konstruktivismus s ohledem na pojmy formuluje takto:

\footnotetext{
${ }^{3}$ Peregrin ve své kritické studii používá termín ,,antirealismus“, který ale zjevně chápe jako zastřešující pojem pro různé verze konstruktivismu.

${ }^{4}$ RRTD, s. 67.

${ }^{5}$ Tamtéž.

${ }^{6}$ Tamtéž, s. 69.
} 
„Věci můžeme znát jen nakolik spadají pod naše pojmová schémata, tudižz nemůžeme vědět, že známe věci tak, jak jsou samy o sobě. “7

Peregrinovi tato inference připadá natolik nezpochybnitelná, že pro ni nepřináší žádné další důkazy. Já naopak nechápu, v čem má její domnělá platnost spočívat. Peregrin spolu se mnou odmítá ${ }^{8}$ podobně znějící vyvození, které ve své knize po vzoru Davida Stova nazývám „,nejhorším argumentem na světě“:

„Věci můžeme znát jen nakolik spadaji pod naše pojmová schémata, tudíz nemůžeme znát věci tak, jak jsou samy o sobě. “9

Peregrin tedy tvrdí: to, že při popisování reality vždy nutně využíváme nějaké pojmové schéma, nám sice přímo nezamezuje v poznání věcí samotných - nejsme navěky uzavřeni uvnitř svých pojmových schémat -, ale znemožňuje nám to poznat, kdy tak činíme a kdy nikoli. Proč? To Peregrin nevysvětluje.

At' už ale Peregrina k této tezi přivedly jakékoli důvody, chtěl bych zdůraznit, že realismus, tak jak ho chápu já, Devitt, Searle a další autoři, je ontologická teze. Je to teze o povaze reality. To, zda tuto realitu můžeme poznat tak, jak je, nebo nemůžeme, je z hlediska vymezení realismu druhotné. Klíčové je, zda předpokládáme, že realita má strukturu sama o sobě, nebo jestli je její struktura závislá na lidské mysli. Je potom pravda, že realismus jako jakousi abstraktní možnost připouští i to, že svět, jak je sám o sobě, leží zcela mimo dosah našich pojmových schémat a i těch nejlepších vědeckých teorií. ${ }^{10}$ Realista však nemá důvod se $\mathrm{k}$ této tezi upínat, pokud nemá $\mathrm{k}$ tak př́ísné skepsi pádné důvody. Např. já jsem ve své knize obhajoval verzi devittovského externího realismu, podle které se svět skládá právě z těch druhů předmětů, které (a) běžně pokládáme za jsoucí, nebo které (b) postulují nejlepší vědecké teorie (jež překonaly fázi pouze slibných hypotéz). Když mne tedy Peregrin obviňuje, že se někdy vyjadřuji tak, ,jako by to, jaké pojmy používáme pro náš popis světa, nemělo nic společného s tím, jak je tento svět sám o sobě (těmito pojmy můžeme nanejvýš jeho skutečnou strukturu postihnout více nebo méně úspěšně) “, ${ }^{11}$ nepřijde mi to zcela fér. Domnívám se totiž - a v knize tomu věnuji určitý prostor -, že kauzálně a evolučně toho mají naše pojmy, popisy a teorie se světem společného hodně. Pojmy, popisy a teorie jsou všechno věci, jež jsou tvarovány vnějším světem; nejsou to nástroje, které tvarují jej. „Pak se ale musíme ptát,“ pokračuje Peregrin, ,jaký je rozdíl mezi pojmy svět a svět-jak-je-pro-nás. A odpověd', že to jsou dvě naprosto různé věci, nás podle mne vede do náručí neudržitelného kantovského dualismu fenoménů a nouménů.“ To je možné, ale to není můj problém. Peregrin se ze mě přesto za každou cenu snaží udělat někoho, kdo přijímá

\footnotetext{
${ }^{7}$ Tamtéž.

${ }^{8}$ Tamtéž.

${ }^{9}$ RR, s. 87.

${ }^{10}$ Viz Putnam (1978, s. 125) a Button (2013, s. 10).

${ }^{11}$ RRTD, s. 66.
} 
kantovskou dualitu jevů a věci o sobě a kdo vydává věc o sobě za vzor toho, co je reálné. Kant podle některých interpretů právě toto činí, ${ }^{12}$ já se ale od takové teorie chci důrazně distancovat. Kant označuje za skandál filozofie, že existence předmětů vně nás není zcela spolehlivě prokázána. Mně jako nemenší filozofický skandál přijde to, že se mu bez jakéhokoli zdůvodnění podařilo široce prosadit názor, že náš poznávací aparát je apriorně předpřipraven $\mathrm{k}$ tvarování a uspořádávání vnější reality (pomocí forem názoru a kategorií). Právě tuto představu subjektu jako zcela odtrženého od prostředí, které ho formuje, chápu jako antitezi realismu, který v knize obhajuji, a jako jednu z tezí filozofického novověku, které je nejvyšší čas odložit do sběru.

Myslím si nicméně, že reálná vzdálenost mezi mým a Peregrinovým pojetím vztahu pojmů a světa je nakonec menší, než jak by se mohlo na první pohled zdát. Oba, domnívám se, chceme zajistit, aby svět byl v těsném kontaktu s bytostmi, které ho v pojmech uchopují. Peregrin se ale ode mne liší ve svém přesvědčení, že ,,svět nemůže být v podstatě nic moc jiného než svět-jak-je-pro-nás“, jež ho vede k sympatii k názoru, že „V jistém smyslu můžeme říci, že svět se $\mathrm{v}$ průběhu evoluce lidské rasy značně změnil““. ${ }^{13}$ Podobné vyjádření nalezneme na s. 72 jeho textu:

„...pokud nechceme termínem svět označovat nějakou zcela chimérickou věc o sobě, musíme, zdá se mi, připustit, že svět není nezávislý na způsobu, jak ho vnímáme a prostřednictvím jakých pojmů ho poznáváme, a tak není nesmyslné říkat, že jsme instituováním těchto pojmů $\mathrm{v}$ jistém smyslu (zdůrazňuji: v jistém smyslu!) dali tomuto světu onen tvar, jaký má.“14

Je tak zřejmé, že Peregrin používá podobnou strategii jako Rorty: jeho „oficiální“ stanovisko je takové, že debata realismus/konstruktivismus je nerozhodnutelná a měli bychom ji opustit. Jakmile se ale pustí do kritizování představ realistů, začne sklouzávat ke konstruktivistickému pojetí. Angažovat se ve sporu realistů s konstruktivisty tedy není úplně „,marnost nad marnost“, jak si Peregrin posteskl v závěrečné větě svého př́spěvku: konstruktivistické řešení je podle něj v jistém smyslu správné.

Není však zřejmé, v jakém smyslu má mít konstruktivista kus pravdy. Pojd’me se proto blíže podívat na pojem světa-jak-je-pro-nás, který v Peregrinovi sympatie s konstruktivistou vzbuzuje. Peregrin není př́liš explicitní, můj dojem ale je, že světjak-je-pro-nás je svět, který je vymezen pojmy a teoriemi, které přijímáme. To, že se „Svět v průběhu evoluce lidské rasy značně změnil“" si pak vykládám ne jako banální tvrzení o fyzických proměnách světa $\mathrm{v}$ čase, ale jako tezi, že obsah pojmu světa se $\mathrm{v}$ průběhu evoluce proměňoval. $\mathrm{V}$ průběhu lidské evoluce, zejména $\mathrm{v}$ posledních staletích, se objevovaly nové pojmy a teorie, zatímco jiné pojmy a teorie - např. teorie o plochosti Země - byly opuštěny. To je pravda, nyní už zbývá jen ukázat, v čem to

\footnotetext{
${ }^{12}$ Viz Neujahr (1995, s. 53).

${ }^{13}$ RRTD, s. 66.

${ }^{14}$ Tamtéž, s. 72.
} 
nahrává konstruktivistovi. To, jak lidé chápali svět před vznikem moderní fyziky, se jistě lišilo od toho, jak svět vnímáme dnes. Otázka platnosti realismu ale tímto faktem není dotčena. Pokud bych měl jako realista vstřícně charakterizovat Peregrinův pojem světa-jak-je-pro-nás, řekl bych, že je to ta část na nás nezávislého SVĚTA, který jsme zatím dokázali poznat (plus některé prázdné pojmy a nepravdivé teorie, jejichž prázdnost a nepravdivost při troše štěstí díky empirickému výzkumu časem vyjde najevo). Pokud bych si ale mohl vybrat, nezvolil bych si ani nedostupný svět kantovské věci o sobě, ani svět-jak-je-pro-nás. Oba pojmy jsou důsledkem př́lilišného důrazu na subjekt. Věc o sobě je nedostupná, protože subjekt vtiskává tvar všemu, co může poznat, a jeho poznání se díky tomu omezuje na svět jevů. Pojem světa-jak-je-pro-nás zase naznačuje, že pojmy a teorie jsou platné jen pro nás, tedy že jejich platnost nějak závisí na naší konstituci, našich zájmech apod. Právě tuto představu, kterou explicitně hájí např. Rorty, jsem v RR podrobně kriticky rozebral a shledal ji pochybnou. Nedokázal jsem dát rozumný smysl myšlence, že např. fotosyntéza existuje jen pro nás - znamená to snad, že pro „,někoho jiného“ neexistuje? Peregrin má možná na mysli jiný význam obratu ,pro nás“, ale ten ve svém textu nijak nevysvětluje.

V RR jsem napsal:

„Přijetí jakéhokoli pojmového aparátu je v první řadě věcí klasifikace: vyznačujeme jím hranice jednotlivých předmětů a rozlišujeme jejich druhy. “15

Taková formulace je, přiznávám, poněkud nešikovná, a Peregrin toho naplno využil. Myslím, že pozorným čtenářům bylo zjevné, co mám na mysli: pojmy identifikují určitou nezávislou strukturu ve světě. Samozřejmě jsem nechtěl ani v nejmenším naznačit, že „vyznačování“ je podobné tvarování předmětů z beztvaré matérie světa, jak mi Peregrin podsouvá. Představu světa jako něčeho zcela beztvarého totiž pokládám za zhola nemožnou. Dokážu si představit, že něco má takový tvar, že to budeme svými pojmy jen těžko popisovat. Nedokážu si představit něco, co nemá vi̊bec žádný tvar. V běžném jazyce se slovo „,beztvarý“ používá ve smyslu „,nemající žádný pevný tvar“, nikoli „nemající žádný tvar“. Tak je napřr. nadměrně obézní tělo označeno za beztvaré, protože se v něm ztrácejí obvyklé lidské rysy. Beztvarost (světa) v silném slova smyslu je nicméně konstruktivistickými teoriemi reality předpokládána. $\mathrm{V}$ tom je jedna z jejich slabin: předpokládají něco, co nelze myslet. ${ }^{16}$

\footnotetext{
${ }^{15}$ RR, s. 30.

${ }^{16}$ Nemyslím si, že by někdo ze současných konstruktivistů tíhnul k idealismu starého střihu, kdy svět, včetně své matérie, je závislý na mysli. Peregrin píše na s. 65 RRTD, že „idealismus, podle kterého by stůl, u kterého sedím, či židle, na které sedím, byly čistě výplody mé mysli, dnes v módě opravdu není.“ Skutečně, s tím nelze než souhlasit. Proto jsem v knize nemluvil o idealismu tohoto druhu, ale o konstruktivismu, který je věcí mentální strukturace reality. $\mathrm{K}$ tomuto názoru, jak si lze ověřit $\mathrm{v}$ jejich textech, inklinuje většina autorů, které $\mathrm{v}$ knize probírám.
} 
Realismus by sotva bylo možné chápat jako atraktivní pozici, kdyby nám vnímání nepředstavovalo svět jako bohatě strukturovaný a podléhající všemožným zákonitostem, z nichž mnohé se explicitně snaží pojmenovat věda. Představě světa, který je strukturovaný nezávisle na příspěvku naší, nebo jakékoli jiné mysli, je díky tomu zcela přirozená: kdyby svět byl sám o sobě neuspořádaný, jak by v nás mohl vyvolávat uspořádané vjemy? Pokud bychom měli alespoň náznaky dokladů pro to, že svět potřebuje uspořádávat, byla by motivace pro konstruktivistické pojetí srozumitelnější. Pokud bychom napřr. měli možnost zakoušet kantovskou „rozmanitost“ před domnělým zásahem forem názoru, bylo by namístě zvažovat myšlenku, že svět je námi uspořádáván. Jenže „rozmanitost“ je jen zcela nezdůvodněný teoretický postulát Kantovy epistemologie. ${ }^{17}$ Obecněji řečeno, pro „světatvorné“ schopnosti subjektu nemáme pražádné doklady. Obhájci subjektivního (či intersubjektivního) konstruktérství by museli bud' odhalit nějaké mechanismy, kterými uspořádávání reality provádíme, ${ }^{18}$ nebo by aspoň museli upozornit na radikální odlišnosti v tom, jak svět uspořádávají odlišné kultury. Nic takového nikdy nebylo konstruktivisty doloženo. V RR jsem na příkladu probíraných autorů, od Quina po Rortyho, ukazoval, že přes více či méně explicitní sympatie ke konstruktivismu ani jeden z nich nedává žádné příklady toho, že by se alternativní popisy světa skutečně radikálně rozcházely. Naopak, jejich vlastní prŕíklady poukazují na to, že svět je i bez našeho přispění determinovaný natolik, že nás „nutí“, abychom jej popisovali určitým způsobem. V knize proto hovořím o „Jednom správném popisu“ světa, který lze obměňovat spíš jen kosmeticky, v nepř́liš podstatných detailech.

Peregrin mi dále vyčítá, že teze realismu je v mé knize formulovaná tak, že neexistuje nic, co bychom přijali jako její vyvrácení. ${ }^{19} \mathrm{~S}$ tím bych rovněž nesouhlasil. Např. kdyby se skutečně prokázalo, že odlišné kultury dramaticky odlišně uspořádávají svět, byl by to ne sice zcela rozhodující, ale v každém případě nezanedbatelný argument pro ontologický konstruktivismus. Objevení takových odlišností by mohlo sehrát podobnou roli, jakou by mělo objevení zkameněliny králíka v prekambrijských geologických vrstvách pro platnost evoluční teorie. ${ }^{20}$ Faktem však zůstává, že žádné takové dramatické odlišnosti mezi kulturami doloženy nebyly. Mezikulturní antropologické a lingvistické výzkumy, jak zdůraznil již Davidson ve svých pracích k pojmovému relativismu, upozorňují spíš jen na lokální odchylky a zvláštnosti, z nichž mnohé jsou vysvětlitelné prostou odlišností geografických podmínek a kulturních

\footnotetext{
${ }^{17}$ Na to upozornil již Rorty (2012, s. 149).

${ }^{18}$ Beru to tak, že v Kantově době ještě postulování takových záhadných schopností nějak prošlo, ale dnes již je bez solidních důkazů neomluvitelné.

${ }^{19}$ RRTD, s. 73.

${ }^{20}$ Jedná se o vrstvy utvořené do období cca před 540 miliony let. Tento př́klad možného důkazu proti platnosti evoluční teorie bývá připisován biologovi J. B. S. Haldanovi.
} 
zvyklostí. $^{21}$ Konstruktivista na to může odpovědět, že konstrukce světa nutně probíhá jen jedním způsobem, a že tedy z tohoto důvodu mezi zkonstruovanými světy nemohou existovat rozdíly. To by však bylo jen další zcela nepodložené tvrzení.

Empirické důkazy proti realismu tedy, pokud se nemýlím, zatím nebyly uvedeny. Existují ale nějaké empirické argumenty pro realismus? V knize hovořím o dvou jevech, které lze podle mě chápat jako silnou podporu pro realistické pojetí ontologie. Tím prvním je to, čemu sociobiolog E. O. Wilson říká konsilience. Za tímto pojmem se skrývá náhled, že vědecké teorie nejsou budovány ve vakuu, bez ohledu na poznatky $\mathrm{v}$ jiných oborech. Kupř́kladu biologické teorie by přinejmenším neměly protiřečit teoriím, které přijímá fyzika. Pokud jde o realismus, ten by neměl být v rozporu např. s evoluční teorií. A evoluční teorie nabízí pohled na člověka jako na něco, co je zcela zapuštěno do světa jakožto produkt dlouhodobé selekce prostředím. Fantazie o tom, jak subjekt dává tvar světu, jehož je součástí, nemají z tohoto hlediska šanci na úspěch. Když už chceme mluvit o tvarování, musíme obrátit směr působení: svět tvaruje člověka, včetně jeho poznávacích nástrojů, k nimž patří pojmy. V knize proto souhlasně cituji slova filozofa Roberta G. Meyerse o tom, že darwinovská evoluce favorizuje realismus před jeho rivaly. ${ }^{22}$ Tím druhým jevem jsou pak ty případy, kdy různé, na sobě nezávislé vědecké metody, případně vědci pracující v různých historických obdobích, dospějí k týmž výsledkům. ${ }^{23}$ Takovou shodu lze principy realismu vyložit velmi dobře, zatímco konstruktivista by se $\mathrm{v}$ takových situacích musel uchýlit $\mathrm{k}$ nepřesvědčivé tezi, že různé vědecké metody a různí vědci se shodují díky tomu, že náhodou konstruují realitu tímtéž způsobem.

Tedy abych své stanovisko shrnul: konstruktivistické argumenty nejsou ničím podložené, a zároveň vedou $\mathrm{k}$ absurdním důsledkům (podrobně je probírám $\mathrm{v}$ jednotlivých kapitolách RR). Realismus nejen $\mathrm{k}$ absurdním důsledkům nevede, ale dokonce pro něj existují netriviální, byt' nepř́ímé argumenty. Doufám tedy, že se mi v RR podařilo předvést, že realismus nemusí být jen slepou vírou či ideologií, kterou lze prosazovat pouze rozlíceným mlácením botou do stolu po vzoru Nikity Chruščova. Spor mezi realismem a konstruktivismem lze racionálně rozřešit.

\footnotetext{
${ }^{21}$ Jako příklad těchto mezikulturních odlišností si můžeme vzít třeba pojmy pro barvy. Jsou jazyky, které mají chudší slovník pro barvy než čeština, a jsou jazyky, které mají slovník barev bohatší. Neexistují ale jazyky, které by obsahovaly dramaticky odlišné pojmy pro barvy. A je třeba upozornit i na to, že jazyk při odlišování jednotlivých barev nehraje roli něčeho, co tyto odlišnosti vytváří. Spíše jde o to, že máme-li v našem jazyce slova pro různé barvy, např. pro modrou a zelenou, dokážeme modré a zelené věci odlišovat o něco rychleji než národy, které jazykově mezi modrou a zelenou nerozlišují. Viz k tomu např. Thierry et al. (2009).

${ }^{22}$ RR, s. 113. Viz Meyers (1990, s. 116).

${ }^{23}$ V knize si od Wesleyho Salmona vypůjčuji př́klad o určení Avogadrovy konstanty. K tomuto určení vedla konvergence trrinácti (!) různých způsobů měření. Viz RR, s. 128.
} 


\section{Literatura}

Button, T. (2013): Limits of Realism. Oxford University Press, Oxford.

Marvan, T. (2014): Realismus a relativismus. Academia, Praha.

Meyers, R. G. (1990): „Evolution as a Ground for Realism.“ In Evolution, Cognition and Realism. Studies in Evolutionary Epistemology, Ed. N. Rescher, University Presses of America, Lanham, 1990, s. 111-118.

Neujahr, P. J. (1995): Kant's Idealism. Mercer University Press, Macon.

Peregrin, J (2014): „Realismus, relativismus a trápení ducha,“ Filosofie dnes 6 (2): 6474.

Putnam, H. (1978): „Realism and Reason.“ In Meaning and the Moral Sciences. Routledge and Kegan Paul, London, s. 123-138.

Rorty, R. (2012): Filosofie a zrcadlo př́rody. Academia, Praha.

Thierry, G. et al. (2009): „Unconscious Effects of Language-Specific Terminology on Preattentive Color Perception," Proceedings of the National Academy of Sciences of the United States of America 106 (11): 4567-4570. 